\title{
Plants as alternative platforms for monoclonal antibodies productions.
}

\author{
Natalia Glumińska ${ }^{1}$ and Magdalena Krzesłowska ${ }^{1}$ \\ ${ }^{1}$ Adam Mickiewicz University
}

July 12, 2021

\begin{abstract}
Monoclonal antibodies (mAbs) are widely used in medical therapy and diagnostics, veterinary therapy, and research. The demand for mAbs reaches several dozen tons per year and is constantly growing, approaching the limits of current production possibilities. Mammalian expression systems, which currently dominate the bioproduction industry, have limited production capacity and require high capital investment and production costs. Plants are becoming promising expression platforms due to their scalability, speed, low cost of production, low risk of contamination from animal pathogens and eukaryotic mechanisms of post-translational protein modification. The transgenic plants used for the production of mAbs can be obtained by stable transformation of plant cells as well as transient expression of foreign proteins. In this review, we extract a broad overview of articles, many of them from recent years, concerning modern approaches to producing monoclonal antibodies in plants, methods for modifying the carbohydrate profile of mAbs, and purifying the resulting product. We also present current data on the practical use of mAbs in medical therapies and potential methods of producing antibodies on a very large scale, able to meet the future market demand.
\end{abstract}

\section{Hosted file}

manuskrypt.docx available at https://authorea.com/users/425210/articles/530076-plants-asalternative-platforms-for-monoclonal-antibodies-productions

Hosted file

Tables.docx available at https://authorea.com/users/425210/articles/530076-plants-asalternative-platforms-for-monoclonal-antibodies-productions 

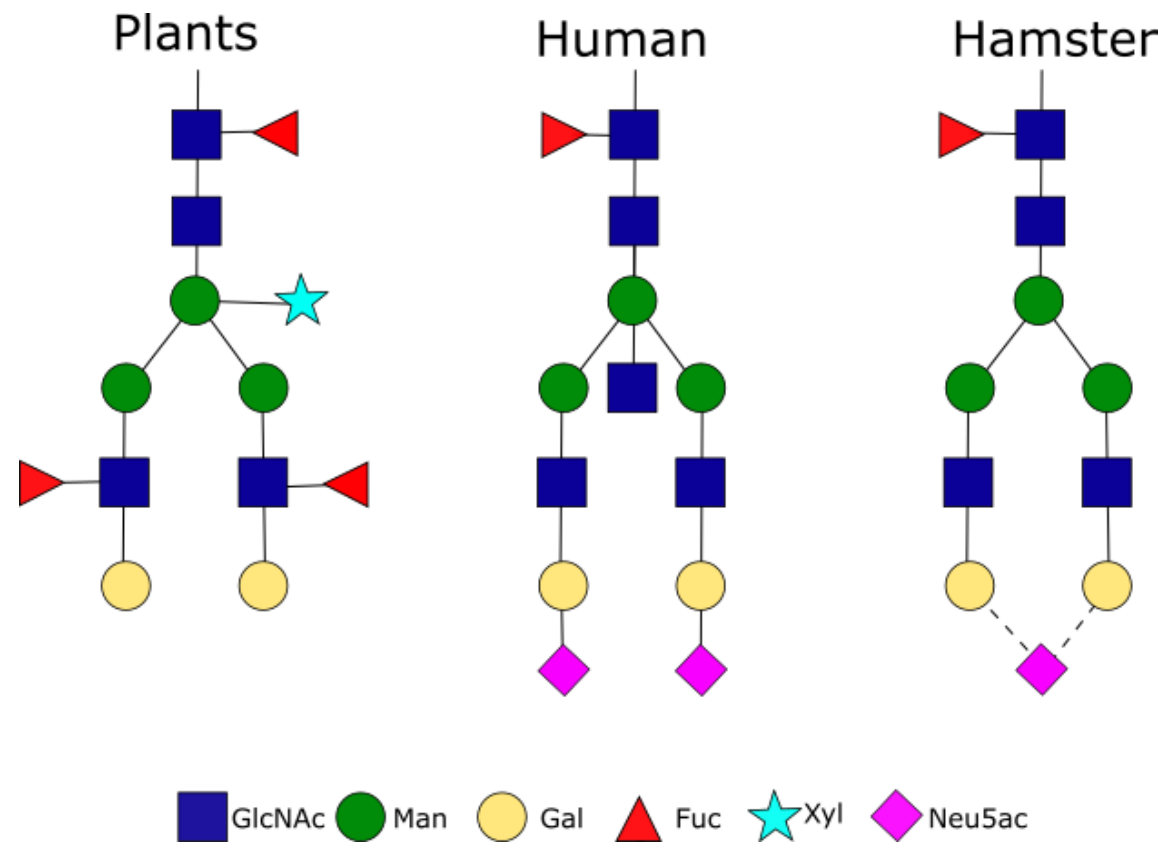

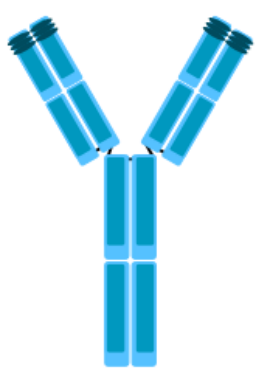

Murine $\mathrm{mAb}$

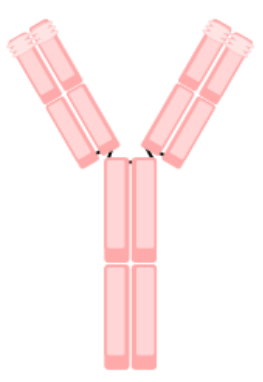

Human mAb

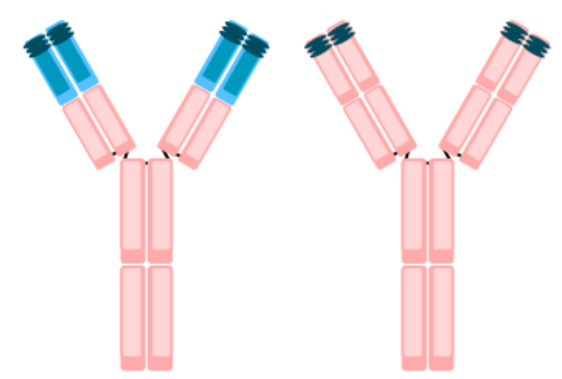

Chimeric mAb Humanized mAb 